\title{
THE POLLEN MORPHOLOGICAL DIVERSITY OF ZIZIPHORA CLINOPODIOIDES (LAMIACEAE)
}

\author{
R. TABARIPour ${ }^{1 *}$, M. Sheidai $^{1}$, S. M. TALEbi ${ }^{2}$ and Z. Noormohammadi ${ }^{3}$ \\ ${ }^{1}$ Faculty of Life Sciences and Biotechnology, Shahid Beheshti University, Tehran, Iran \\ E-mail: *Raheleh.tp@gmail.com, msheidai@yahoo.com, msheidai@sbu.ac.ir \\ ${ }^{2}$ Department of Biology, Faculty of Science, Arak University, Arak, Iran \\ E-mail: seyedmehdi_talebi@yahoo.com \\ ${ }^{3}$ Department of Biology, Sciences and Research Branch, Islamic Azad University, Tehran, Iran \\ E-mail:marjannm@yahoo.com,z-nouri@srbiau.ac.ir
}

(Received: 06 June, 2018; Accepted: 22 May, 2019)

\begin{abstract}
A cogent medicinal and aromatic plant, Ziziphora clinopodioides (Lamiaceae) is a perennial herb, its aerial parts is used as a wild vegetable or additive in foods to proffer pleasant aroma and flavour. There are many discussions about the intraspecific classification of this species and several subspecies have been introduced for it in different flora. These subspecies are morphologically very similar and identification of them is very difficult and in some cases, impossible. Therefore, in the present study, the pollen grains morphology of nine subspecies (32 specimens) of Z. clinopodioides were probed and documented in details utilising the scanning electron microscopy (SEM). In total, eleven pollen morphological characteristics were investigated and analysed by PAST software. The obtained results showed that pollen grains were hexacolpate and their equatorial views were sub-oblate to prolate. The exine ornamentation types of the pollen grains are bireticulate, microreticulate, reticulate and bireticulate-reticulate. The ANOVA test did not show significant difference for the studied quantitative traits. Although, the results of the multivariate analysis revealed a high diversity amongst the specimens even in the specimens of a single subspecies; it did not confirm the separation of subspecies in Z. clinopodioides.
\end{abstract}

Key words: exine ornamentation, Lamiaceae, pollen diversity, SEM, Ziziphora clinopodioides

\section{INTRODUCTION}

Ziziphora L. (Lamiaceae) consists of 25 to 30 species in East and West Asia, Central Europe, North African (Keshavarzi et al. 2008). Four species of it, Ziziphora clinopodioides Lam., Ziziphora capitata L., Ziziphora persica Bunge and Ziziphora tenuior L. naturally grow in Iran (Jamzad 2012, Rechinger 1982). Furthermore the only perennial Ziziphora species is Z. clinopodioides, which is known as "Kakuti-e-kuhi" or "Taramoshk" in Iran. It is a medicinal and aromatic plant that is used as wild vegetable or additive in foods to offer aroma and flavour (Khodaverdi-Samani et al. 2015). In the Iranian tradition medicine, this species is used as a sedative or carminative, for/in stomachic, and 
common cold, diarrhoea, coughing and wound healing material (Ghasemi Pirbalouti et al. 2013, Naghibi et al. 2005, Öztürk et al. 1995, Tarakci 2004).

Ziziphora clinopodioides Lam. has prostrated to erect stems and is mainly much branched from the base. The leaves vary in size and shape. Inflorescence is terminal with a compact capitulum. The calyx measures 4-7 $\mathrm{mm}$ and the corolla measures up to $8 \mathrm{~mm}$. The flowers are glabrous to densely hirsute, purplish pink to white, with or without a peduncle. It grows in steppes and stony slopes (Keshavarzi et al. 2008).

There is consensus on the exact numbers of the subspecies of Z. clinopodioides that should be recognised. For example, it is divided into four subgroups (i.e. rigida, glabrata, tomentosa and canescens) based on large calyx and corolla structure, leaf morphology, nutlet and sexual characters (Hedge 1961). In the Flora Iranica (Rechinger 1982), nine subspecies have been introduced for Iran (subsp. afghanica (Rech. f.) Rech. f., subsp. bungeana (Juz.) Rech. f., subsp. elbursensis (Rech. f.) Rech. f., subsp. filicaulis (Rech. f.) Rech. f., subsp. pseudodasyantha (Rech. f.) Rech. f., subsp. kurdica (Rech. f.) Rech. f., subsp. rigida (Boiss.) Rech. f., subsp. ronnigeri (Nábělek) Rech. f., and subsp. szowitsii (Rech. f.) Rech. f.). This species in the Flora of Iran (Jamzad 2012) and Turkish flora (Edmondson 1982), however, is not divided into subspecies.

The pollen grain morphology in Lamiaceae has proven to be a quintessential purpose for the classification within this family (Abu-Asab and Cantino 1992). The pollen morphology has been adopted as a tool for demonstrating the taxonomic and phylogenetic importance of taxa in different genera of Lamiaceae, such as Phlomis L., Marrubium L., Stachys L., Nepeta L., Mentha L., Ziziphora L. and Ajuga L. (Abu-Asab and Cantino 1994, Celenk et al. 2008a, b. Harley et al. 1992, Jamzad et al. 2006, Kose et al. 2011, Moon et al. 2008a, b, Tabaripour et al. 2018, Wagstaff 1992). Little research has been conducted on the genus Ziziphora. Moreover, in the anatomical studies, just the cross sections taken mainly from the stems and leaves have been reported (Keshavarzi et al. 2008, Koca and Tümen 1996, Koca et al. 1995, Sezik and Tümen 1984, 1988). The micro-morphological and pollen grain studies have been focused on four subspecies of Z. clinopodioides (Keshavarzi et al. 2008). Selvi et al. (2013) investigated the pollen morphology of the five species from Turkey.

The palynological characters of $Z$. clinopodioides are variable even among several populations of the same subspecies (Keshavarzi et al. 2008). For this reason and lacking of comprehensive study on the subspecies, this study was conducted for the first time in the world; hence, the aims of the present paper were twofold: (i) to determine whether the pollen characters could differentiate the subspecies of $Z$. clinopodioides by scanning electron microscopy (SEM) and (ii) to assess the taxonomic significance of the pollen grain morphology. 


\section{MATERIAL AND METHODS}

\section{Plant material}

In the current investigation, pollen grains morphology of nine subspecies (32 specimens) of Ziziphora clinopodioides were studied by scanning electron microscopy (SEM). The subspecies were identified based on the descriptions provided in the Flora Iranica (Rechinger 1982) and some samples were not identified in subspecies level, for the reason of overlapping in morphological characters of several subspecies.

The pollen samples were obtained mostly from herbarium materials. Voucher specimens have been deposited in Shahid Beheshti University Herbarium (HSBU), Herbarium Ministerii Iranici Agriculturae (IRAN) and Herbarium of Natural History Museum (W) (Table 1).

\section{Scanning electron microscopy}

Small quantities of pollen grains were transferred directly to aluminium stubs with double-sided cellophane tape and coated with gold. The specimens were examined using a Philips $\times$ L20 scanning electron microscopes (SEM). UTHSCSA Image Tool Version 3.0 was used to carry out required measurements. Pollen terminology follows Erdtman (1952), Punt et al. (2007) and Hesse et al. (2009).

\section{Statistical analysis}

Ten to 30 fully developed pollen grains were randomly selected for analysis. Eight quantitative and three qualitative palynological features were used for multivariate analysis including the shape (basically, was determined by ration of the equatorial length / polar length $(\mathrm{P} / \mathrm{E})$ ), polar axis length $(\mathrm{P})$, equatorial axis length $(\mathrm{E})$, diameter of perforation $(\mathrm{DP})$, diameter of muri (DM), apocolpium length (AI), length of colpus (LC), distance between colpi ends (T), number of perforation in $25 \mu^{2}$ area (NP) and pattern of sculpturing of pollen (SC) (Table 2).

The analysis of variance (ANOVA) test was performed to detect significant difference for palynological characters of the studied subspecies.

Multivariate analysis including MDS (multidimensional scaling), PCO (principal coordinates analysis) and UPGMA (unweighted pair group method with arithmetic mean) were performed using PAST ver. 2.17 software, for plotting variation among the populations (Hammer et al. 2001). For grouping 
Table 1

Specimen information for populations of Ziziphora clinopodioides sampled, including herbarium vouchers for specimens

\begin{tabular}{|c|c|c|c|c|}
\hline $\begin{array}{l}\text { Pop. } \\
\text { no. }\end{array}$ & Features & Locality & No. & $\begin{array}{l}\text { Voucher } \\
\text { number }\end{array}$ \\
\hline 1 & Z. clinopodioides subsp.?* & $\begin{array}{l}\text { Razavi Khorasan, Torbat-e Hey- } \\
\text { darieh }\end{array}$ & 1 & HSBU2014413 \\
\hline 2 & Z. clinopodioides subsp.?* & Razavi Khorasan, northern Kashmar & 1 & HSBU2014414 \\
\hline 3 & Z. clinopodioides subsp.?* & Tehran, Damavand & 2 & HSBU2014425 \\
\hline 4 & Z. clinopodioides subsp.?* & Mazandaran, Sorkh Geriveh village & 2 & HSBU2014426 \\
\hline 5 & Z. clinopodioides subsp.?* & Qazvin, Qastin Lar & 4 & HSBU2014411 \\
\hline 6 & Z. clinopodioides subsp.?* & Mazandaran, Kelardasht & 1 & HSBU2014419 \\
\hline 7 & Z. clinopodioides subsp.?* & Mazandaran, Jurband & 1 & HSBU2014415 \\
\hline 8 & Z. clinopodioides subsp.?* & Mazandaran, Rineh & 1 & HSBU2014423 \\
\hline 9 & Z. clinopodioides subsp.?* & Qazvin, Bahram Abad village & 1 & HSBU2014417 \\
\hline 10 & Z.c. subsp. kurdica & Typus & 1 & W1889-009018 \\
\hline 11 & Z.c. subsp. pseudodasyantha & & 1 & W1966-0021503 \\
\hline 12 & Z.c. subsp. pseudodasyantha & $\begin{array}{l}\text { Razavi Khorasan, Torbat-e Hey- } \\
\text { darieh, Sefid Darreh }\end{array}$ & 1 & 26294(IRAN) \\
\hline 13 & Z.c. subsp. pseudodasyantha & Gilan, Pakdeh village & 1 & 26296/2(IRAN) \\
\hline 14 & Z.c. subsp. elbursensis & Typus & 1 & W1956-0006985 \\
\hline 15 & Z.c. subsp. elbursensis & & 1 & 22286(IRAN) \\
\hline 16 & Z.c. subsp. elbursensis & Tehran & 1 & 26300/1(IRAN) \\
\hline 17 & Z. c. subsp. filicaulis & Typus & 1 & W1956-0006986 \\
\hline 18 & Z. c. subsp. filicaulis & Semnan, kuh-e-Shahvar & 1 & 26292(IRAN) \\
\hline 19 & Z.c. subsp. szowitsii & Typus & 1 & W0031739 \\
\hline 20 & Z.c. subsp. ronningeri & East Azarbaijan, Khoy & 1 & W1984-0001938 \\
\hline 21 & Z.c. subsp. ronningeri & Azarbaijan & 1 & 26357(IRAN) \\
\hline 22 & Z.c. subsp. ronningeri & Azarbaijan & 1 & 26358(IRAN) \\
\hline 23 & Z. c. subsp. afghanica & $\begin{array}{l}\text { Shahroud, Khvosh Yeylaq, gardaneh } \\
\text { Olang }\end{array}$ & 1 & 26289/1(IRAN) \\
\hline 24 & Z. c. subsp. afghanica & $\begin{array}{l}\text { Shahroud, Khvosh Yeylaq, gardaneh } \\
\text { Olang }\end{array}$ & 1 & 26289/3(IRAN) \\
\hline 25 & Z.c. subsp. bungeana & $\begin{array}{l}\text { North Khorasan, Shirvan, Namanlu } \\
\text { village, Galil }\end{array}$ & 1 & 55403(IRAN) \\
\hline 26 & Z.c. subsp. bungeana & Shahroud & 1 & 26290(IRAN) \\
\hline 27 & Z.c. subsp. rigida & Tehran & 1 & 26334/2(IRAN) \\
\hline
\end{tabular}

No. = number of specimens sampled;

* $=$ These samples were not identified in subspecies level because of overlapping on morphological characters of several subspecies 
of the specimens, UPGMA (unweighted paired group with arithmetic average) and MDS plot were performed.

The data were standardised (mean $=0$, variance $=1$ ) for these analyses. Euclidean and taxonomic distance are used among the subspecies (Podani 2000).

\section{RESULTS}

General pollen grain features

Morphological characteristics of the pollen grains of Ziziphora clinopodioides subspecies are displayed in Tables 2 and Figures 1-64. Pollen grains are radially symmetrical, isopolar and hexacolpate monads. The shape of the pollen grains is sub-oblate $(\mathrm{P} / \mathrm{E}=0.82-0.88$; Figs 1,3$)$, oblate-spheroidal $(\mathrm{P} / \mathrm{E}=$
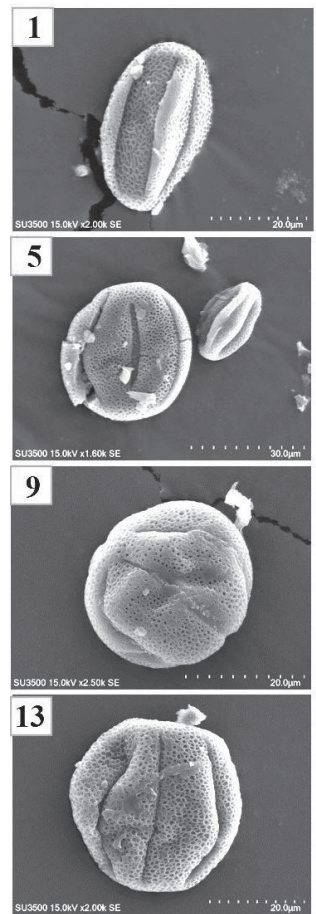
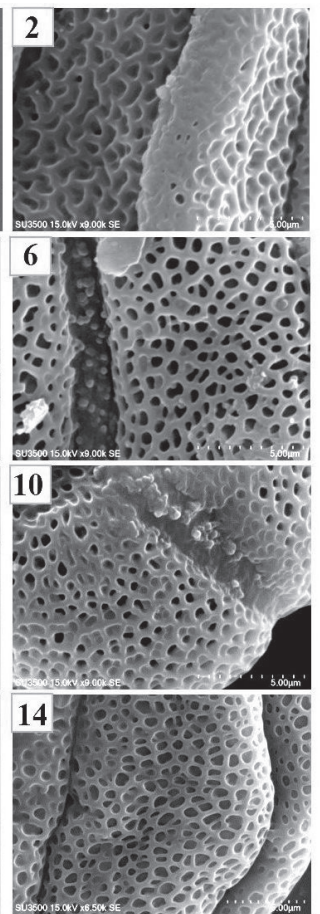
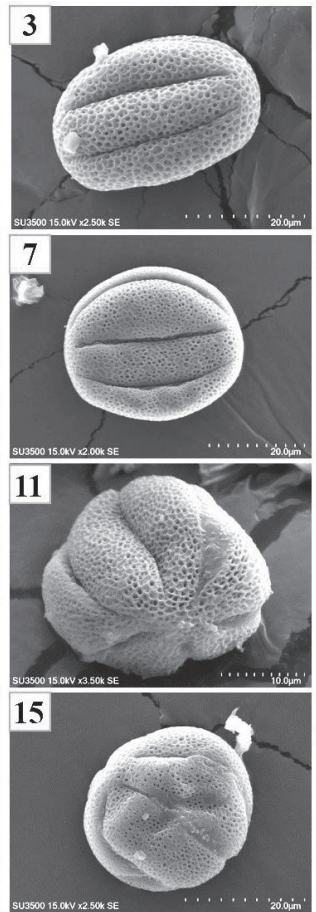
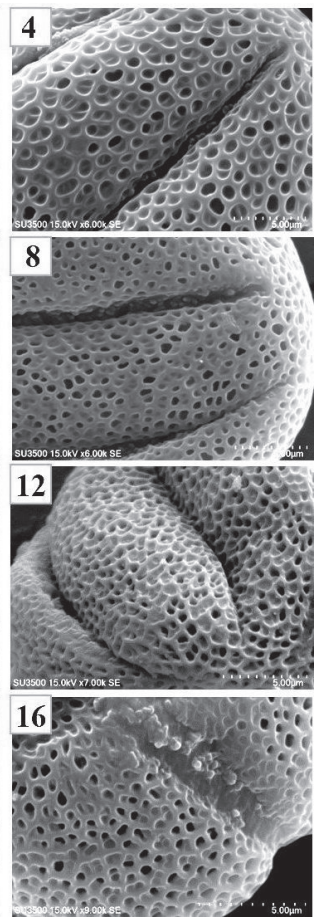

Figs 1-16. SEM micrographs of Z. clinopodioides pollen grains. - Figs 1-2: Z. clinopodioides (Razavi Khorasan, Torbat-e Heydarieh); Figs 3-4: Z. clinopodioides (Razavi Khorasan, northern Kashmar); Figs 5-8: Z. clinopodioides (Tehran, Damavand); Figs 9-12: Z. clinopodioides (Mazandaran, Sorkh Geriveh village); Figs 13-16: Z. clinopodioides (Qazvin, Qastin Lar) (equatorial view: 1, 3, 5, 7, 9, 13 and 15; polar view: 11; exine ornamentation: 2, 4, 6, 8, 10,

12, 14 and 16) 


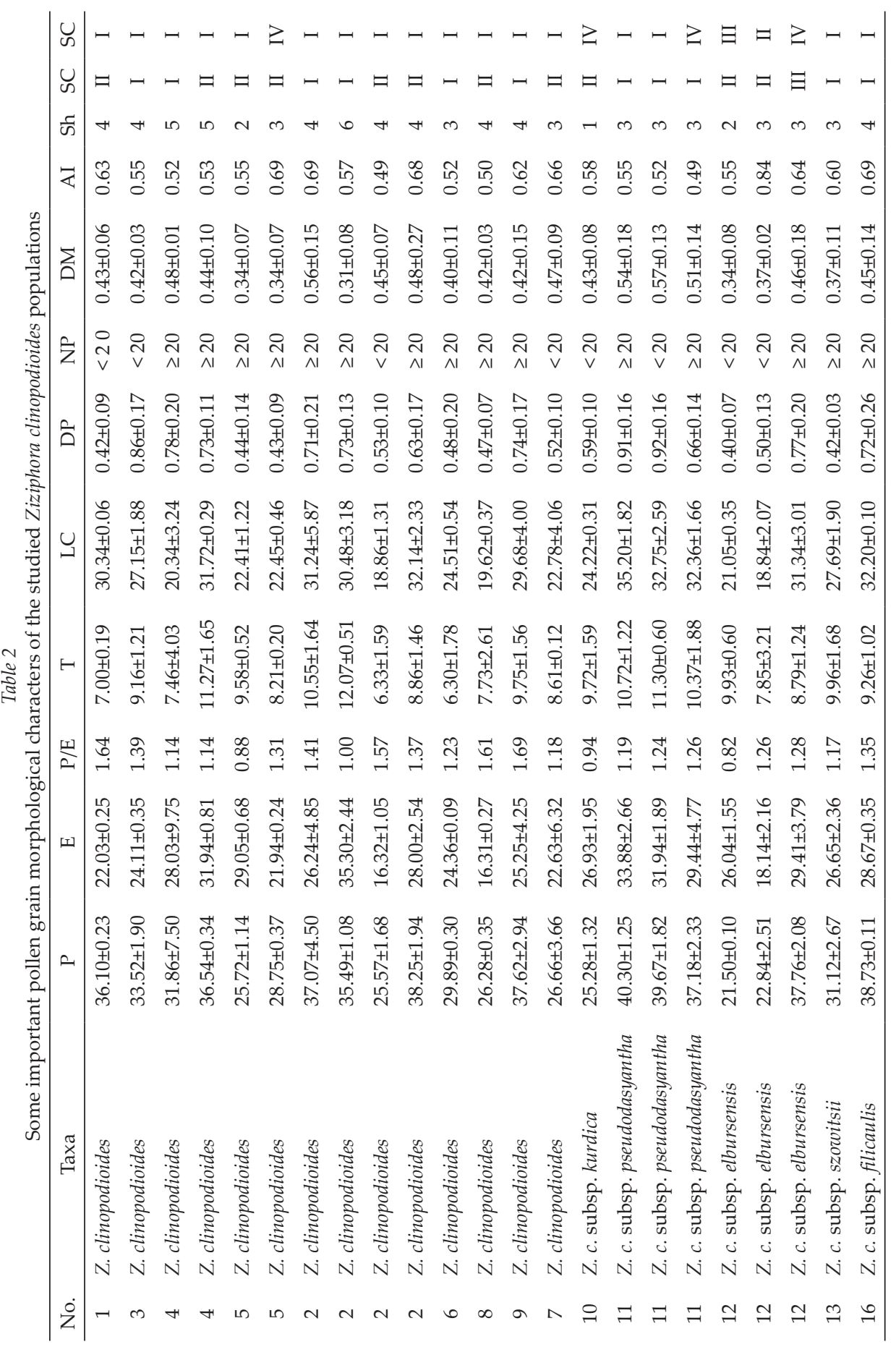




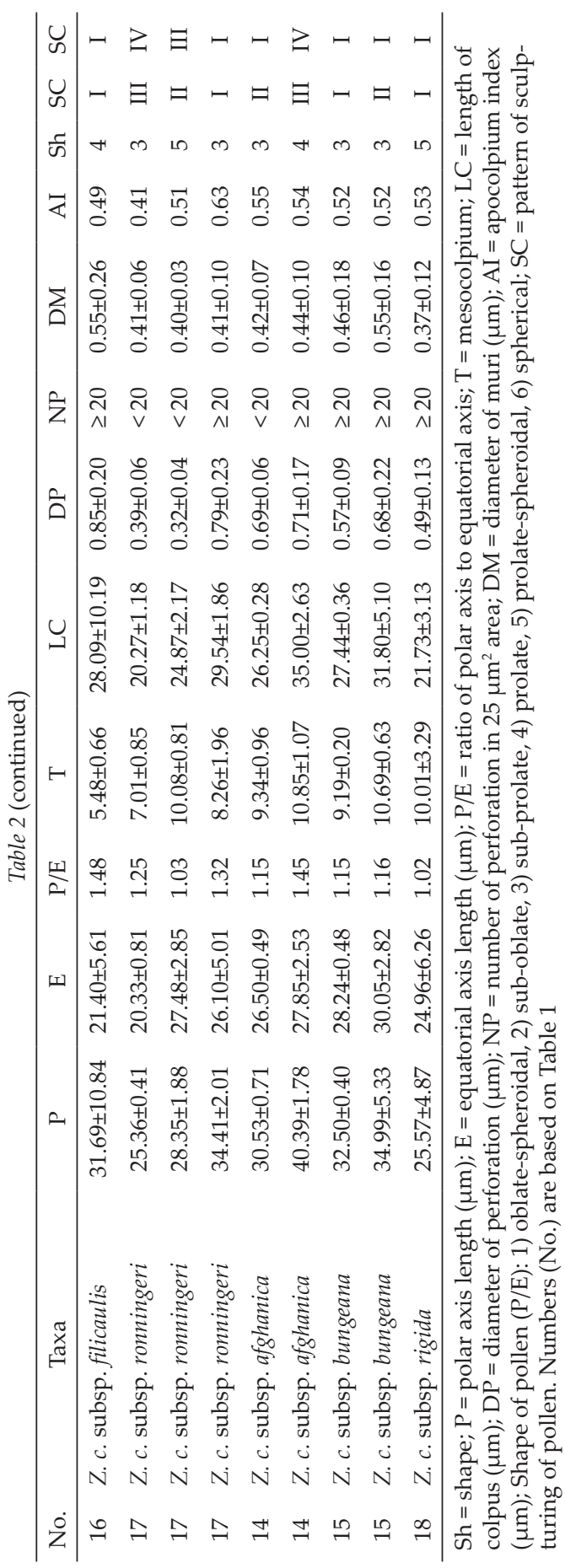

0.94; Figs 29-30), spherical (P/E = 1.00; Figs 1-2), prolate-spheroidal $(\mathrm{P} / \mathrm{E}=1.02-1.14 ;$ Figs 1,4$)$ and subprolate $(\mathrm{P} / \mathrm{E}=1.17-1.31$, Figs 1-4) to prolate $(\mathrm{P} / \mathrm{E}=0.82-$ 1.69; Figs 1-4) in the equatorial view. The polar axis $(\mathrm{P})$ varies between 21.50 to $40.30 \mu \mathrm{m}$, and the equatorial diameter $(\mathrm{E})$ is between 16.31 and $35.30 \mu \mathrm{m}$. The range of the colpus length of all the studied taxa is 18.86$35.20 \mu \mathrm{m}$. The length of the colpus is not correlated with the whole pollen size. The range of the distance between the colpi of all the studied populations is $6.30-12.07 \mu \mathrm{m}$. The apocolpium length (AI) is the ratio of the distance between the apices of two colpus to its equatorial diameter. The ranges of the apocolpium index vary between 0.41 to $0.84 \mu \mathrm{m}$. Colpi are narrow towards the poles and have coarsely granular membranes. The diameters of perforations are between $0.32-0.92$ $\mu \mathrm{m}$.

\section{Exine ornamentation}

Variations are observed in the exine sculpturing ornamentations. The exine of the pollen grains is mainly bireticulate, microreticulate or a combination of these types. Based upon the different pattern of the exine sculpturing, three types can be recognised for Ziziphora clinopodioides: 
Pollen type I: bireticulate ornamentation pattern is the common type of exine ornamentation amongst the studied populations (Figs 3-6, 13-16, 21-22, 25-26, 31-32, 33-36, 43-48, 53-54, 63-64). A bireticulate is comprised of twolayered-reticulum. The brochi of the primary reticulum are filled by a small secondary reticulum and are divided into $2-4$ smaller pieces.

Pollen type II: microreticulate ornamentation (Figs 1-2, 7-12, 17-20, 2324, 27-30, 37-40, 49-52, 55-56, 59-62).

\section{Other exine ornamentation types}

The other rare recognised ornamentations in Ziziphora clinopodioides is bireticulate-reticulate (type III) that was recorded in Z. clinopodioides subsp. elbursensis (Figs 40-41), Z. clinopodioides subsp. ronningeri (Figs 53-54) and Z. clinopodioides subsp. afghanica.
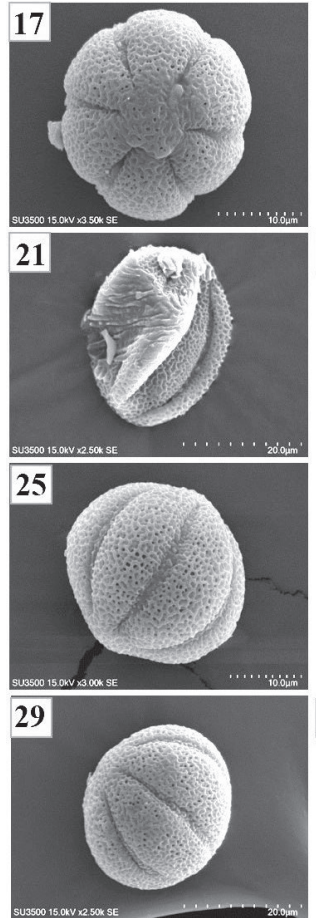
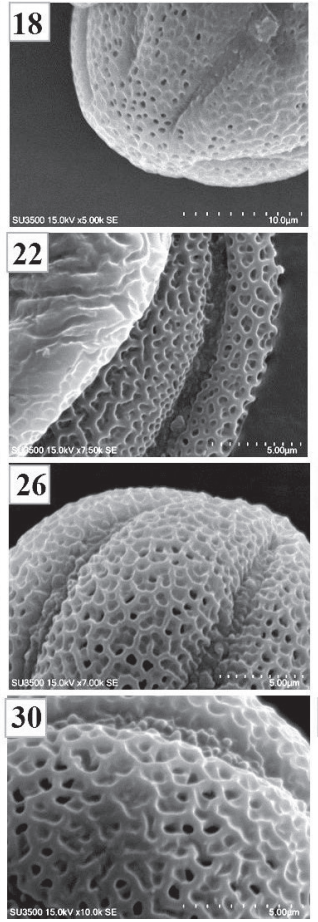
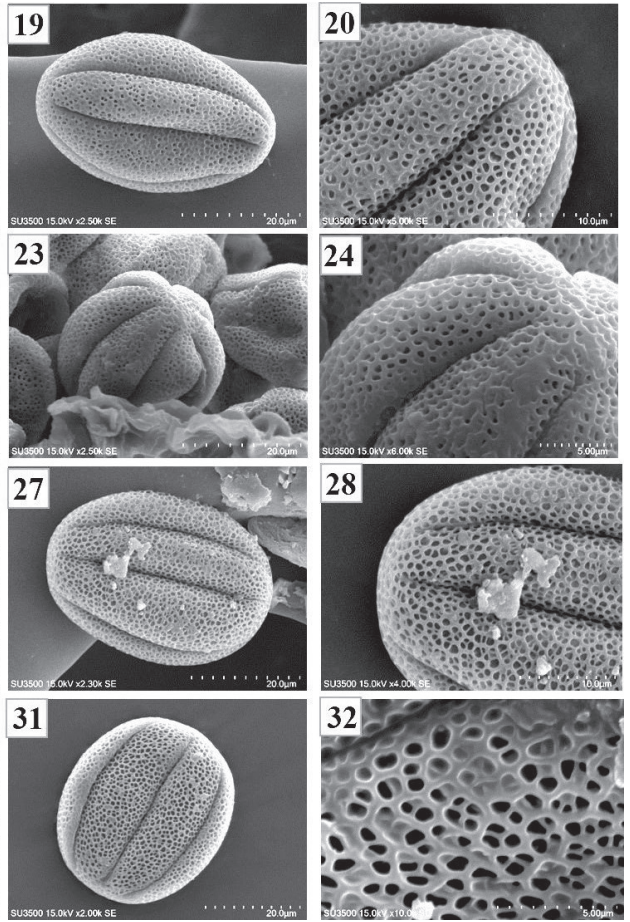

Figs 17-32. SEM micrographs of Z. clinopodioides pollen grains. - Figs 17-20: Z. clinopodioides (Qazvin, Qastin Lar); Figs 21-22: Z. clinopodioides (Mazandaran, Kelardasht); Figs 23-24: Z. clinopodioides (Mazandaran, Jurband); Figs 25-26: Z. clinopodioides (Mazandaran, Rineh); Figs 27-28: Z. clinopodioides (Qazvin, Bahram Abad village); Figs 29-30: Z. clinopodioides subsp. kurdica (Typus); Figs 31-32: Z. clinopodioides subsp. pseudodasyantha (equatorial view: 19, 21, 25, 27, 29 and 31; polar view: 17 and 23; exine ornamentation: 18, 20, 22, 24,

$26,28,30$ and 32 ) 


\section{Infraspecific variation}

The results of ANOVA indicate that there is no significant difference in the quantitative traits of the pollen grains $(p>0.05)$. Moreover, different ordination methods produced similar results therefore, the MDS and PCO plot of the studied populations based on the palynological features are provided (Figs 65-66). The UPGMA, MDS and PCO plot analysis (Figs 65-67) did not support the subspecies classification of the studied populations of Ziziphora clinopodioides. The representatives of the presumed subspecies of the Z. clinopodioides were intermixed in the plot. Therefore, the subspecies were not differentiated by pollen data.

UPGMA tree (Fig. 67) revealed that the studied populations (representative of subspecies) in Z. clinopodioides, overlapped together and they did not form separate clusters; especially individuals were collected from the geo-
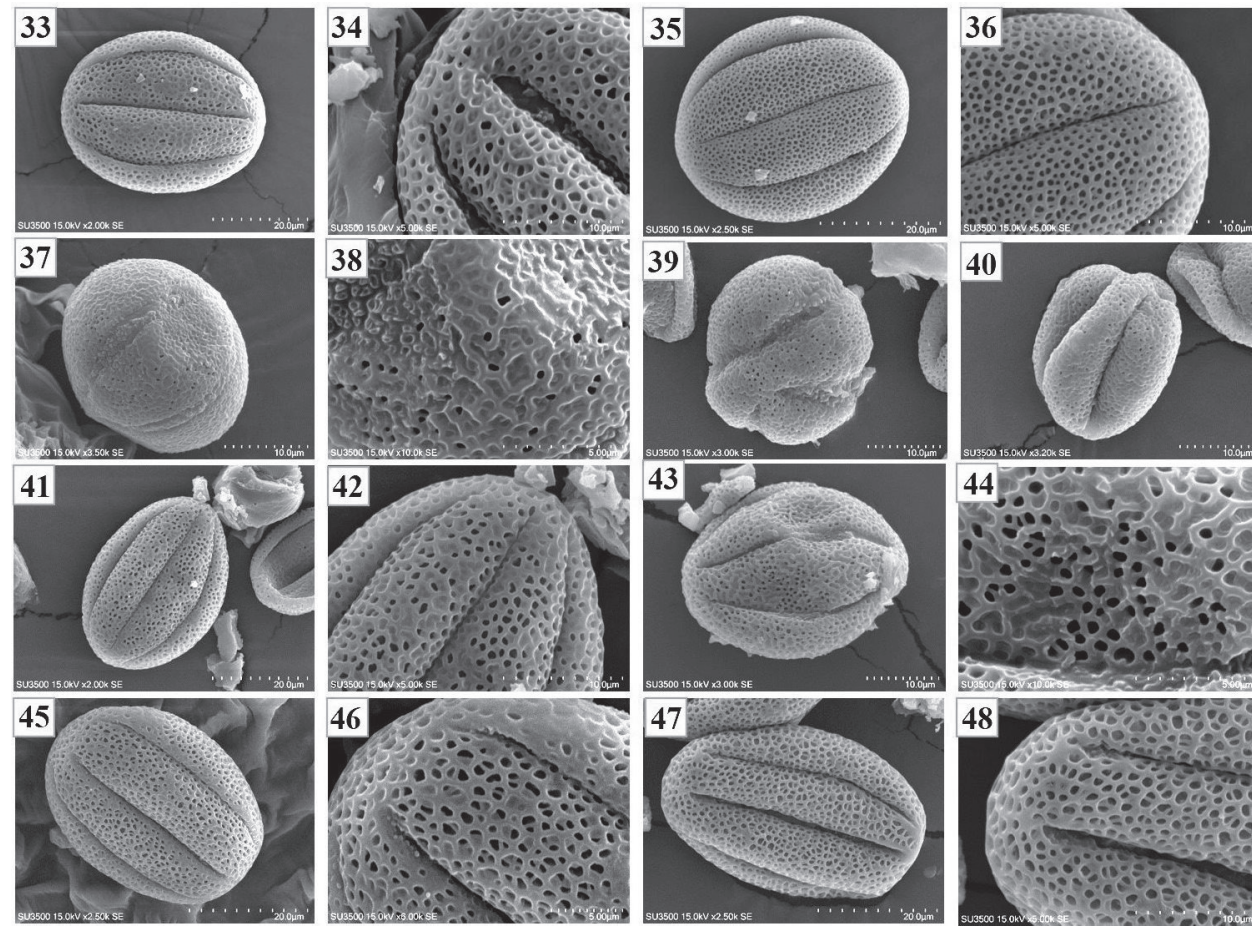

Figs 33-48. SEM micrographs of Z. clinopodioides pollen grains. - Figs 33-36: Z. clinopodioides subsp. pseudodasyantha (Razavi Khorasan, Torbat-e Heydarieh, Sefid Darreh; Gilan, Pakdeh village); Figs 37-42: Z. clinopodioides subsp. elbursensis (type: 39, 40); Figs 43-44: Z. clinopodioides subsp. szowitsii (type); Figs 45-48: Z. clinopodioides subsp. filicaulis (type; Semnan, kuh-e-Shahvar) (equatorial view: 33, 35, 37, 39, 40, 41, 43, 45 and 47; exine ornamentation: $34,36,38,42,44,46$ and 48 ) 
graphical localities of Iran. Therefore, there is little support for the pollen morphology divergence amongst the subspecies.

\section{DISCUSSION}

Ziziphora clinopodioides has a large geographical distribution and represents high morphological diversity in Iran and adjacent countries. Our investigations have revealed that the pollen grain morphology can be useful in clarifying the infra-specific classification (Jamzad and Hasani-Nejad 2014, Keshavarzi et al. 2008, Selvi et al. 2013, Tabaripour et al. 2018), such as the ornamentation of the pollen grains have valuable morphological characteristics to solve taxonomic problems of some subspecies in Ajuga. The sculpture of
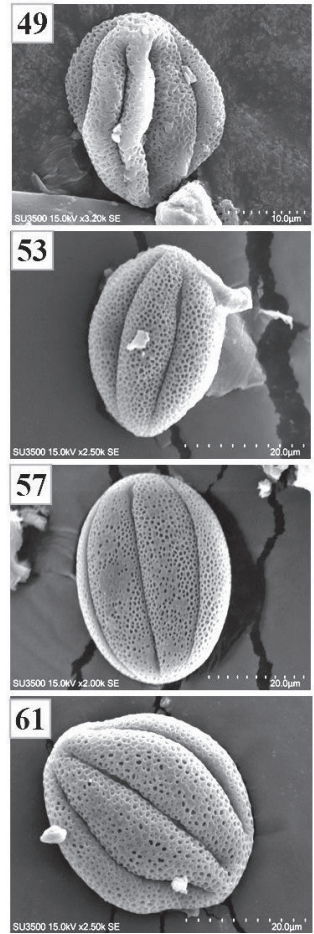
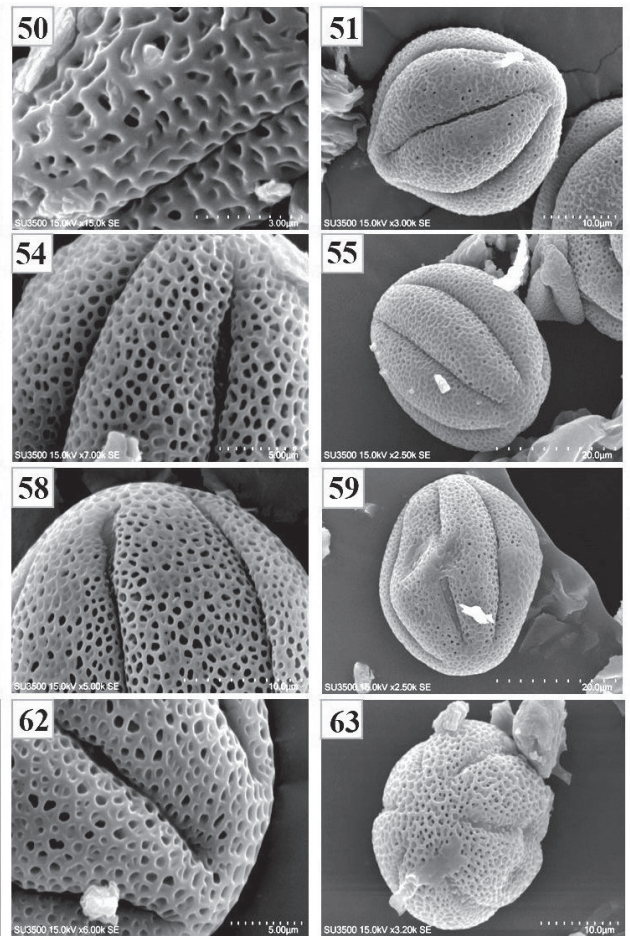
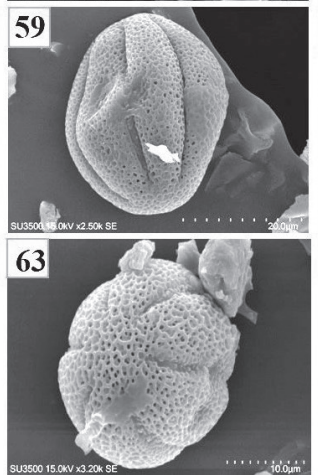
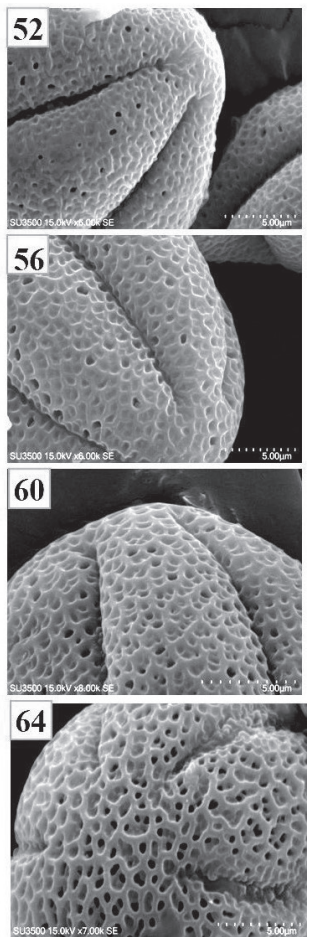

Figs 49-64. SEM micrographs of Z. clinopodioides pollen grains. - Figs 49-54: Z. clinopodioides subsp. ronningeri (East Azarbaijan, Khoy; Azarbaijan; Azarbaijan); Figs 55-58: Z. clinopodioides subsp. afghanica (Shahroud, Khvosh Yeylaq, gardaneh Olang); Figs 59-62: Z. clinopodioides subsp. bungeana (North Khorasan, Shirvan, Namanlu village, Galil; Shahroud); Figs 63-64: Z. clinopodioides subsp. rigida (Tehran) (equatorial view: 49, 51, 53, 55, 57, 59 and 61; polar view: 63 ; exine ornamentation: $50,52,54,56,58,60,62$ and 64 ) 
A. chamaepitys subsp. chia var. chia was granulate, but it was reticulate in $A$. chamaepitys subsp. chia var. ciliata (Kose et al. 2011).

In the present study it was observed that the shape of the pollen grains of Z. clinopodioides are sub-oblate, oblate-spheroidal, spherical, sub-prolate to prolate and the ornamentation is bireticulate, microreticulate, reticulate and bireticulate-reticulate. It was also found that there is a remarkable problem in the case of shape and ornamentation, even in different specimens of the same subspecies.

Moon et al. (2008a) have studied the pollen grain morphology of subtribe Menthinae. They have investigated 58 species from 42 genera including $Z$. clinopodioides and suggested that the pollen grains of this species are hexacolpate, oblate to oblate-spheroidal shape and exine ornamentation is bireticulate. Selvi et al. (2013) have suggested that the pollen grains of Z. clinopodioides are hexacolpate, symmetrical, isopolar, oblate spheroidal to prolate shape and

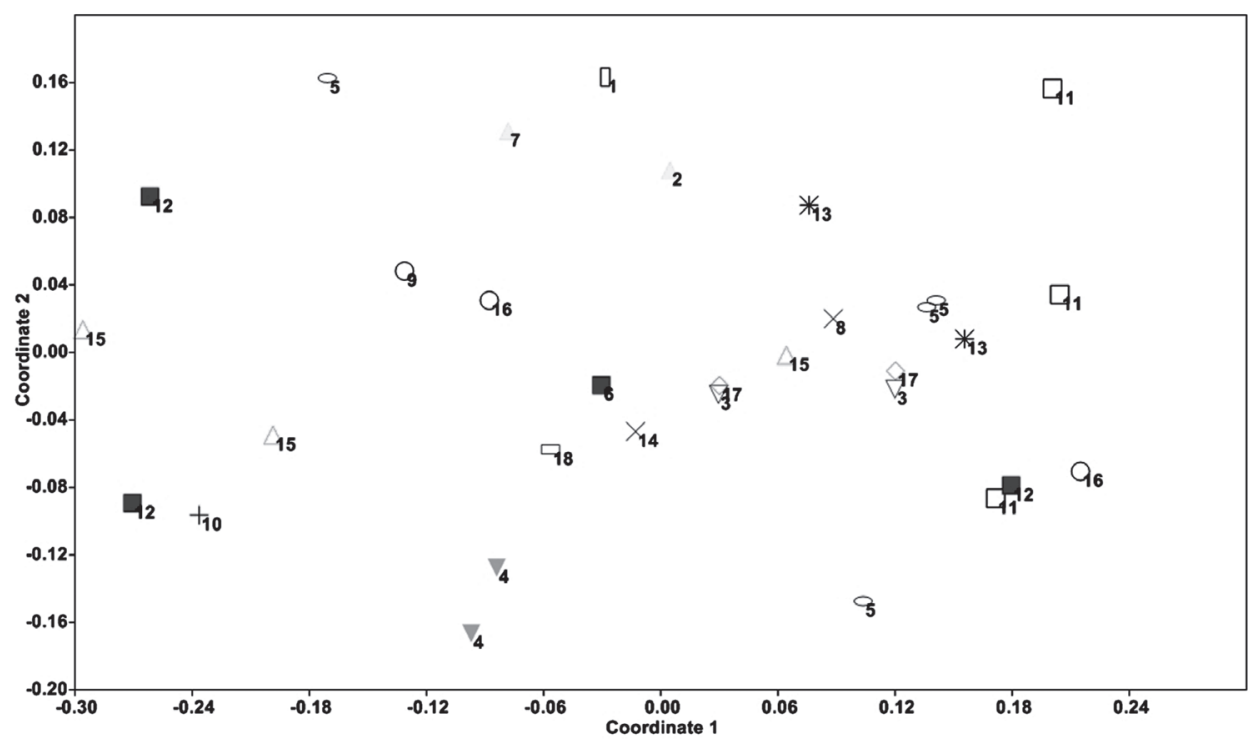

Fig. 65. MDS of the studied Z. clinopodioides populations of based on the palynological data. $1=Z$. clinopodioides (Razavi Khorasan, Torbat-e Heydarieh); $2=Z$. clinopodioides (Razavi Khorasan, northern Kashmar); $3=$ Z. clinopodioides (Tehran, Damavand); $4=$ Z. clinopodioides (Mazandaran, Sorkh Geriveh village); $5=$ Z. clinopodioides (Qazvin, Qastin Lar); $6=Z$. clinopodioides (Mazandaran, Kelardasht); $7=$ Z. clinopodioides (Mazandaran, Jurband); $8=Z$. clinopodioides (Mazandaran, Rineh); $9=$ Z. clinopodioides (Qazvin, Bahram Abad village); 10 $=Z$. clinopodioides subsp. kurdica $; 11=Z$. clinopodioides subsp. $p$ seudodasyantha; $12=Z$. clinopodioides subsp. elbursensis; $13=Z$. clinopodioides subsp. filicaulis; $14=Z$. clinopodioides subsp. szowitsii $; 15=Z$. clinopodioides subsp. ronningeri $; 16=Z$. clinopodioides subsp. afghanica $; 17=$

Z. clinopodioides subsp. bungeana; $18=Z$. clinopodioides subsp. rigida. 
exine sculpturing is bireticulate. Keshavarzi et al. (2008) have observed that the shape of the pollen grains of $Z$. clinopodioides is hexacolpate, prolate, and prolate spheroidal to spheroid and the sculpturing is bireticulate.

Variation in the pollen grains size, the exine ornamentation and aperture numbers occurs in many families, such as Canna indica L. (Chen et al. 1989), Lythrum salicaria L. (Mal and Hermann 2000), Thymus capitatus (Karabournioti et al. 2007), Malus (Nazeri 2008), Pyrus (Zamani et al. 2010) and Acer (Nikzat Siahkolaee et al. 2017). The pollen grain morphology in Rosaceae has a large differentiation in populations of one species. Bednorz et al. (2005) indicated that there are no important differences in the pollen morphology between the subspecies of Sorbus aucuparia.

Most of the Mentha species are characterised by vast morphological variations, as reflected by the large number of names at different taxonomic ranks attributed by the taxonomists to the mints during the past two centuries. Furthermore, the intra- and interspecific hybridisation occurs commonly when

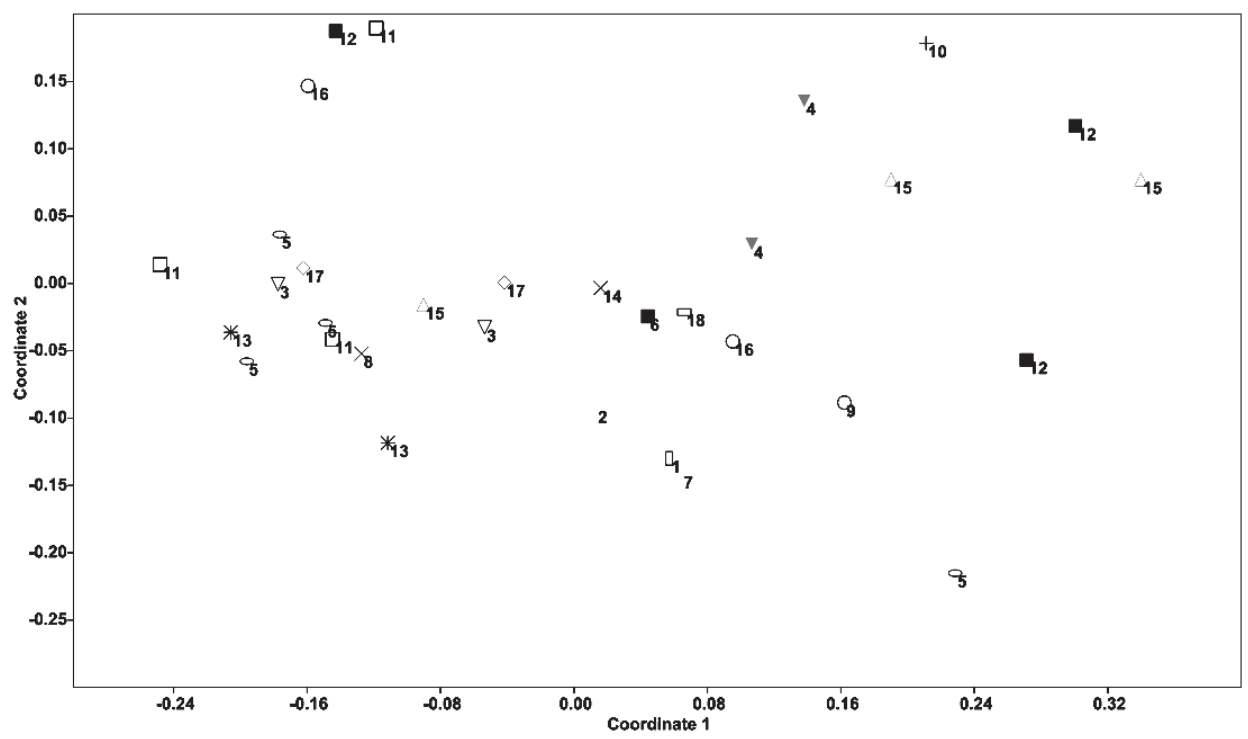

Fig. 66. PCO plot of the studied Z. clinopodioides populations based on the palynological data. $1=$ Z. clinopodioides (Razavi Khorasan, Torbat-e Heydarieh); $2=Z$. clinopodioides (Razavi Khorasan, northern Kashmar); 3 = Z. clinopodioides (Tehran, Damavand); 4 = Z. clinopodioides (Mazandaran, Sorkh Geriveh village); $5=$ Z. clinopodioides (Qazvin, Qastin Lar); $6=$ Z. clinopodioides (Mazandaran, Kelardasht); $7=$ Z. clinopodioides (Mazandaran, Jurband); $8=$ Z. clinopodioides (Mazandaran, Rineh); $9=$ Z. clinopodioides (Qazvin, Bahram Abad village); $10=Z$. clinopodioides subsp. kurdica; $11=$ Z. clinopodioides subsp. $p$ seudodasyantha; 12 $=Z$. clinopodioides subsp. elbursensis; $13=Z$. clinopodioides subsp. filicaulis; $14=Z$. clinopodioides subsp. szowitsii; $15=Z$. clinopodioides subsp. ronningeri; $16=Z$. clinopodioides subsp. afghanica; $17=Z$. clinopodioides subsp. bungeana; $18=Z$. clinopodioides subsp. rigida 
the species of section Menthae section meets sympatrically with each other, leading to the complex variation patterns that characterise most of the wild populations (Celenk et al. 2008b).

Supporting the ANOVA results, the MDS, PCO plot and UPGMA tree did not separate the studied subspecies based on the qualitative and quantitative characters. Therefore, combination of the UPGMA and PCO plot indicated a palynological divergence amongst the probed subspecies.

Rechinger (1982) in the Flora Iranica has introduced this variety in the form of subspecies. In this paper, the pollen characters indicated that there are no subspecies in the studied populations of $Z$. clinopodioides. The findings of the present study confirm the previous study performed by Jamzad (2012) in the Flora of Iran; after thorough morphological investigation in Z. clinopodioides, Jamzad (2012) stated that due to the high degree of morphological variability and co-occurrence of many subspecies in one location, the number of subspecies within $Z$. clinopodioides cannot be determined with absolute cer-

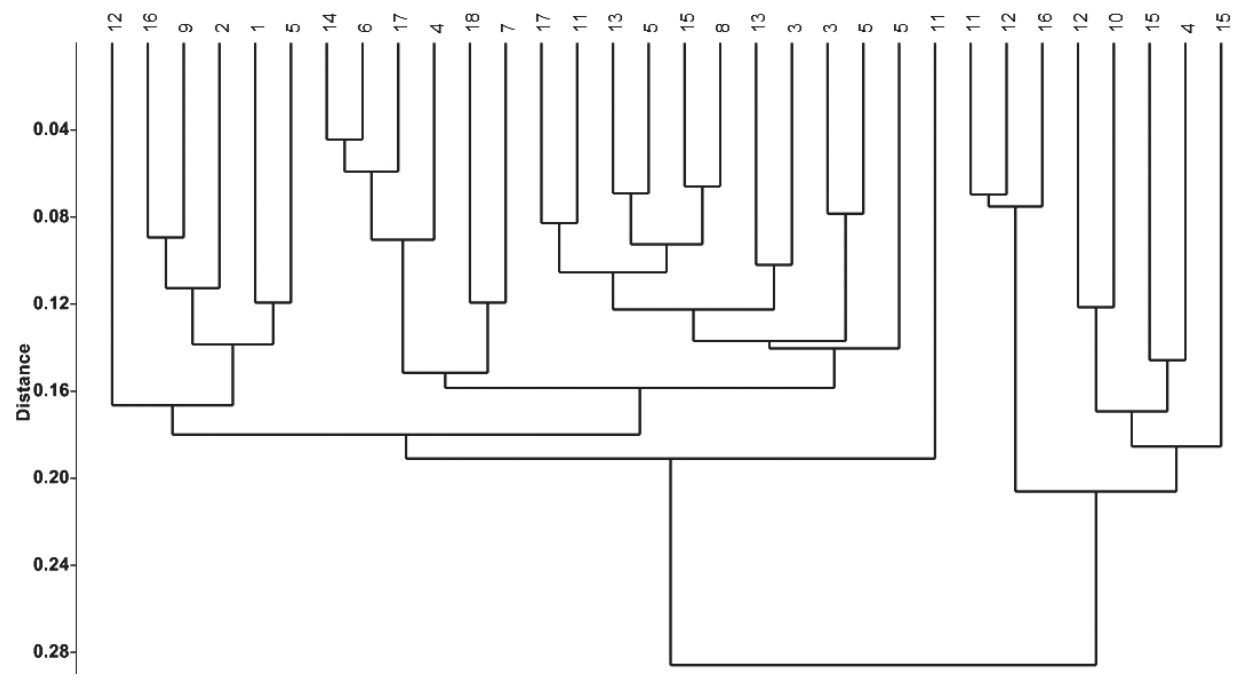

Fig. 67. UPGMA tree of the studied populations of Z. clinopodioides based on the palynological data. $1=Z$. clinopodioides (Razavi Khorasan, Torbat-e Heydarieh); $2=Z$. clinopodioides (Razavi Khorasan, northern Kashmar); $3=$ Z. clinopodioides (Tehran, Damavand); $4=$ Z. clinopodioides (Mazandaran, Sorkh Geriveh village); $5=$ Z. clinopodioides (Qazvin, Qastin Lar); $6=Z$. clinopodioides (Mazandaran, Kelardasht); $7=Z$. clinopodioides (Mazandaran, Jurband); $8=$ Z. clinopodioides (Mazandaran, Rineh); $9=$ Z. clinopodioides (Qazvin, Bahram Abad village); $10=Z$. clinopodioides subsp. kurdica; $11=Z$. clinopodioides subsp. pseudodasyantha; 12 $=Z$. clinopodioides subsp. elbursensis; $13=Z$. clinopodioides subsp. filicaulis; $14=Z$. clinopodioides subsp. szowitsii; $15=Z$. clinopodioides subsp. ronningeri; $16=Z$. clinopodioides subsp. afghanica; $17=Z$. clinopodioides subsp. bungeana; $18=$ Z. clinopodioides subsp. rigida 
tainty. Keshavarzi et al. (2008) reported that Z. clinopodioides subsp. elbursensis has not been distinctly separated from subsp. rigida, subsp. pseudodasyantha and subsp. szowitsii, however, it was identified to be clearly separated. The present study, nonetheless, did not confirm this finding. It was found that all the subspecies are distributed among each other.

The delimitation of $\mathrm{Z}$. clinopodioides into subspecies is not quite easy (Jamzad 2012). The major reason for the introgression or the introgressive hybridisation is the incorporation (usually via hybridisation and backcrossing) of alleles from one entity (species) into the gene pool of a second, divergent entity (species) (Anderson and Hubricht 1938, Harrison and Larson 2014).

\section{CONCLUSIONS}

There have been numerous discussions about intraspecific classification of Ziziphora clinopodioides. To this end, various subspecies have been definite for it in different flora. These subspecies are morphologically very similar; therefore, the palynological traits were used for the identification and delimitation of the subspecies. The present study unveiled that the palynological features that have been deemed useful for the idea of including the subspecies in the Z. clinopodioides are not approved. Therefore, these variables have little taxonomic value for the identification amongst the subspecies of Z. clinopodioides. It can be stated that the finding by Jamzad (2012) for the intraspecific classification and introducing all subspecies to be synonymous were confirmed in the present paper.

$*$

Acknowledgements - We wish to thank the Dr Ernst Vitek of following herbaria W and IRAN for permission to remove pollen from herbarium specimens and Iran National Science Foundation (INSF) with 95813755 Number for partial financial supporting. We are also grateful to Saeed Javadi Anaghizi in Central laboratory of the Shahid Beheshti University for providing SEM pictures.

\section{REFERENCES}

Abu-Asab, M. S. and Cantino, P. D. (1992): Pollen morphology in subfamily Lamioideae (Lamiaceae) and its phylogenetic implications. - In: Harley, R. M. and Reynolds, T. (eds): Advances in Labiatae science. Royal Botanic Gardens, Kew, pp. 97-112.

Abu-Asab, M. S. and Cantino, P. D. (1994): Systematic implications of pollen morphology in subfamilies Lamioideae and Pogostemonoideae (Labiatae). - Ann. Mo. Bot. Garden 81: 653-686. https://doi.org/10.2307/2399915 
Anderson, E. and Hubricht, L. (1938): Hybridization in Tradescantia. III. The evidence for introgressive hybridization. - Amer. J. Bot. 25(6): 396-402. https://doi. org/10.1002/j.1537-2197.1938.tb09237.x

Bednorz, L., Maciejewska-Rutkowska, I., Wrońska-Pilarek, D. and Fujiki, T. (2005): Pollen morphology of the Polish species of the genus Sorbus L. - Acta Soc. Bot. Pol. 74(4): 315-322. https://doi.org/10.5586/asbp.2005.040

Celenk, S., Dirmenci, T., Malyer, H. and Bicakc1, A. (2008a): A palynological study of the genus Nepeta L. (Lamiaceae). - Plant Syst. Evol. 276(1-2): 105-123. https://doi. org/10.1007/s00606-008-0062-7

Celenk, S., Tarımcilar, G., Bicakc1, A., Kaynak, G. and Malyer, H. (2008b): A palynological study of the genus Mentha L. (Lamiaceae). - Bot. J. Linn. Soc. 157(1): 141-154. https:// doi.org/10.1111/j.1095-8339.2008.00789.x

Chen, F., Ciampolini, F., Tiezzi, A. and Cresti, M. (1989): The ultrastructure of polymorphic pollen grains of Canna indica L. - Sex. Plant Reprod. 2(3): 193-198. https://doi. org/10.1007/bf00192766

Edmondson, J. R. (1982): Ziziphora L. - In: Davis, P. H. (ed.): Flora of Turkey and the East Aegean Islands. Vol. 7. Edinburgh University Press, Edinburgh, pp. 395-399.

Erdtman, G. (1952): Pollen morphology and plant taxonomy, Angiosperms. - Almquist and Wiksell, Stockholm resp. Hafner Publ. Comp., New York (1971).

Ghasemi Pirbalouti, A., Amirkhosravi, A., Bordbar, F. and Hamedi, B. (2013): Diversity in the chemical composition of essential oils of Ziziphora tenuior as a potential source of pulegone. - Chemija 24(3): 234-239.

Hammer, Ø., Harper, D. A. T. and Ryan, P. D. (2001): PAST: Paleontological statistical software package for education and data analysis. - Palaeontol. Electron. 4(1): 1-9.

Harley, M. M., Paton, A., Harley, R. M. and Cade, P. G. (1992): Pollen morphological studies in Ocimeae (Nepetoideae, Labiatae): I. Ocimum L. - Grana 31(3): 161-176. https:// doi.org/10.1080/00173139209432027

Harrison, R. and Larson, E. L. (2014): Hybridization, introgression, and the nature of species boundaries. - J. Hered. 105: 795-809. https://doi.org/10.1093/jhered/esu033

Hedge, I. C. (1961): Some remarks on the perennial species of Ziziphora with special reference to those in Turkey. - Ann. Roy. Bot. Gard. 23: 209-221.

Hesse, M., Halbritter, H., Zetter, R., Weber, M., Buchner, R., Frosch-Radivo, A. and Ulrich, S. (2009): Pollen terminology, an illustrated handbook. - Springer, Vienna.

Jamzad, Z. (2012): Lamiaceae. - Flora of Iran, no. 76, Research Institute of Forests and Rangelands, Tehran.

Jamzad, Z. and Hasani-Nejad, M. (2014): Taxonomic implications of pollen exine morphology in infrageneric classification of Scutellaria (Lamiaceae). - Nord. J. Bot. 32(2): 233244. https://doi.org/10.1111/j.1756-1051.2012.00054.x

Jamzad, Z., Abbas, A. R. and Dehghan, M. (2006): Pollen morphology and staminal structure in Salvia and Zhumeria (Lamiaceae). - Rostaniha 7 (Suppl. 2): 283-298.

Karabournioti, S., Eleftheriou, E. P., Thrasyvoulou, A. and Fasseas, C. (2007): Pollen polymorphism in Thymus capitatus (Lamiaceae). - Can. J. Bot. 85(5): 493-500. https://doi. org/10.1139/b07-048

Keshavarzi, M., Jahandideh, R. and Bokaee, Z. N. (2008): Morphological and anatomical studies on Ziziphora clinopodioides Lam. (Labiatae). - Pak. J. Biol. Sci. 11(23): 2599_ 2605. https://doi.org/10.3923/pjbs.2008.2599.2605

Khodaverdi-Samani, H., Ghasemi Pirbalouti, A., Shirmardi, H. A. and Malekpoor, F. (2015): Chemical composition of essential oils of Ziziphora clinopodioides Lam. (endemic 
Iranian herbs) collected from different natural habitats. - Indian J. Tradit. Knowl. 14(1): 57-62.

Koca, F. and Tümen, G. (1996): Türkiye'de Aromatik bir bitki: Ziziphora tenuior L.' nin morfolojik ve anatomik özellikleri. XI. Bitkisel Ilac Hammaddeleri Toplantısı. - Eczacılık Fakültesi Yayınları, Ankara Üniversitesi, Ankara, pp. 203-214.

Koca, F., Erken, S., Tümen, G. and Baser, K. H. C. (1995): Ziziphora clinopodioides Lam. Uzerinde Morfolojik ve Anatomik Araştırmalar. - Turk. J. Bot. 19: 135-144.

Kose, Y. B., Erkara, I. P. and Alan, S. (2011). Pollen morphology of some Turkish Ajuga L. (Lamiaceae) and its taxonomic value. - Bangl. J. Bot. 40(1): 29-33. https://doi. org/10.3329/bjb.v40i1.7994

Mal, T., and Hermann, B. (2000): Quantitative evaluation of pollen polymorphism in a tristylous weed, Lythrum salicaria (Lythraceae). - Can. J. Bot. 78(8): 1086-1094. https:// doi.org/10.1139/cjb-78-8-1086

Moon, H. K., Vinckier, S., Smets, E. and Huysmans, S. (2008a): Palynological evolutionary trends within the tribe Menthinae (Nepetoideae: Lamiaceae). - Plant Syst. Evol. 275(1-2): 93-108. https://doi.org/10.1007/s00606-008-0042-y

Moon, H. K., Vinckier, S., Walker, J. B., Smets, E. and Huysmans, S. (2008b): A search for phylogenetically informative pollen characters in the subtribe Salviinae (Mentheae: Lamiaceae). - Int. J. Plant Sci. 169(3): 455-471. https://doi.org/10.1086/526463

Naghibi, F., Mosaddegh, M., Motamed, S. M. and Ghorbani, A. (2005): Labiatae family in folk medicine in Iran: from ethnobotany to pharmacology. - Iran. J. Pharmaceut. Res. 2: 63-79. https://doi.org/10.22037/IJPR.2010.619

Nazeri, J., V. (2008): Pollen morphology of the genus Malus (Rosaceae). - Iran. J. Sci. Technol. 32(2): 89-97. https://doi.org/10.22099/IJSTS.2008.2246

Nikzat Siahkolaee, S., Sheidai, M., Assadi, M. and Noormohammadi, Z. (2017): Pollen morphological diversity in the genus Acer L. (Sapindaceae) in Iran. - Acta Biol. Szeged. 61(1): 95-104.

Öztürk, Y., Aydin, S., Tecik, B. and Başer, K. H. C. (1995): Effects of essential oils from Ziziphora species on swimming performance in mice. - Phytother Res. 9(3): 225-227. https://doi.org/10.1002/ptr.2650090315

Podani, J. (2000): Introduction to the exploration of multivariate biological data. English translation. - Backhuys Publishers, Leiden, 407 pp.

Punt, W., Hoen, P. P., Blackmore, S., Nilsson, S. and Le Thomas, A. (2007): Glossary of pollen and spore terminology. - Rev. Palaeobot. Palynol. 143(1-2): 1-81. https://doi. org/10.1016/j.revpalbo.2006.06.008

Rechinger, K. H. (1982): Labiatae. - In: Rechinger, K. H. (ed.): Flora Iranica. Akademische Druck- und Verlagsanstalt, Graz, Austria, pp. 25-44.

Selvi, S., Satil, F., Martin, E., Celenk, S. and Dirmenci, T. (2013): Some evidence for infrageneric classification in Ziziphora L. (Lamiaceae: Mentheae). - Plant Biosyst. 149(2): 415-423. https://doi.org/10.1080/11263504.2013.853701

Sezik, E., and Tümen, G. (1984): Morphological and anatomical studies on plant used as folk medicine and plant tea in Turkey-II, Ziziphora taurica Bieb subsp. taurica. - Doğa Bilimleri Dergisi 8: 98-103.

Sezik, E. and Tümen, G. (1988): Morphological and anatomical investigations on the plant used as folk medicine and herbal tea in Turkey VI. Ziziphora taurica Bieb. subsp. cleonioides (Boiss.) Davis. - J. Uludag Univ. Fac. Edu. 3(2): 65-73.

Tabaripour, R., Sheidai, M., Talebi, S. M. and Noormohammadi, Z. (2018): Genetic divergence and speciation within Ziziphora capitata (Lamiaceae): molecular and mi- 
cromorphological evidences. - Biodiversitas, J. Biol. Div. 19(2): 747-755. https://doi. org/10.13057/biodiv/d190250

Tarakci, Z., Coskun, H. and Tuncturk, Y. (2004): Some properties of fresh and ripened herby cheese, a traditional variety produced in Turkey. - Food Technol. Biotech. 42(1): 47-50.

Wagstaff, S. J. (1992): A phylogenetic interpretation of pollen morphology in tribe Mentheae (Labiatae). - In: Harley, R. M. and Reynolds, T. (eds): Advances in Labiate science. Royal Botanic Gardens, Kew, pp. 113-142.

Zamani, A., Attar, F. and Maroofi, H. (2010): Pollen morphology of the genus Pyrus (Rosaceae) in Iran. - Acta Biol. Szeged. 54(1): 51-56. 
